\title{
Characterization of Expression of Puumala Virus Nucleocapsid Protein in Transgenic Plants
}

\author{
Shahryar Khattak ${ }^{a}$ Gholamreza Darai ${ }^{b}$ Sandor Sülec Angela Rösen-Wolffa \\ aKlinik und Poliklinik für Kinder- und J ugendmedizin, Universitätsklinikum Carl Gustav Carus Dresden, \\ Technische Universität Dresden, Dresden, bInstitut für Medizinische Virologie, Universität Heidelberg, \\ Heidelberg, Germany; 'CHungarian Academy of Sciences, Budapest, Hungary
}

\section{Key Words}

Hantavirus · Nucleocapsid protein · Expression .

Tobacco $\cdot$ Potato

\begin{abstract}
Transgenic plants expressing a foreign gene are a suitable system for the production of relevant immunogens in high amounts that can be used for the development of a new generation of vaccines against a variety of infectious diseases. In the present study, the expression of the nucleocapsid $(\mathrm{N})$ protein of hantavirus serotype Puumala in tobacco and potato plants was investigated. Transgenic tobacco and potato plants were generated and established. These transgenic plants expressed the $\mathrm{N}$ protein of Puumala virus strain CG-1820. No major differences were observed when the phenotype and growth rates of transgenic plants were compared to those of normal plants. However, it was found that the leaves of transgenic tobacco plants were more slender and the tubers of transgenic potato plants were smaller than those in normal plants. In order to investigate the distribution of the expression of the foreign gene in transgenic plants, the proteins of leaves and roots of the individual transgenic tobacco and potato plants were examined by Western blot analyses. It was found that all
\end{abstract}

transgenic tobacco and potato plants expressed the $\mathrm{N}$ protein in the leaves, whereas transgenic potato plants are able to significantly express the viral proteins also in the tubers and roots. The antigens were expressed at a level of $1 \mathrm{ng}$ of protein $/ 5 \mu \mathrm{g}$ of dried leaves. The hantaviral recombinant $\mathrm{N}$ proteins obtained from transgenic tobacco and potato plants were able to elicit specific humoral and mucosal immune responses when administered intraperitoneally or orally to rabbits and mice. The expression of viral proteins in plants has two major advantages compared to other expression systems: firstly, there is no risk of contamination with mammalian viruses or other pathogens, and secondly, the production of high amounts of antigens is cheap and therefore of great economic interest.

Copyright @2003S. Karger AG, Basel

\section{Introduction}

Hantaviruses are negative-sense, single-stranded RNA viruses [1] that belong to the Bunyaviridae family. Different serotypes are etiologic agents of a number of diseases with renal and/or pulmonary involvement, ranging from the more benign nephropathia epidemica (lethality $0.1-$ $1 \%)$ through hemorrhagic fever with renal syndrome (le-

\section{KARGER}

Fax +41613061234 E-Mail karger@karger.ch www.karger.com
(C) 2002 S. Karger AG, Basel

0300-5526/02/0456-0334\$18.50/0

Accessible online at: www. karger.com/int
Angela Rösen-Wolff, MD, PhD

Klinik und Poliklinik für Kinder- und Jugendmedizin

Universitätsklinikum Carl Gustav Carus Dresden, Technische Universität Dresden Fetscherstrasse 74, D-01307 Dresden (Germany)

Tel. +49 351458 6673, Fax +49 351458 6333, E-Mail klifo@rcs.urz.tu-dresden.de 
thality $3-10 \%$ ) to the hantavirus pulmonary syndrome (lethality $>50 \%$ ). The individual hantavirus genotypes are carried by specific rodent hosts. Infection of humans occurs by aerosol inhalation of contaminated rodent excretions.

The three-segment genome of hantaviruses codes for the viral RNA-dependent RNA polymerase (L-RNA segment), the glycoproteins G1 and G2 (M-RNA segment) and the viral nucleocapsid protein (S-RNA segment). The viral nucleocapsid protein is an important structural protein and is essential for packaging of the RNA segments and encapsidation [2]. Major antigenic domains of hantaviruses are also located on the nucleocapsid protein [3]. The early immune response is mainly directed against this structural protein, and sera of convalescent patients predominantly contain antibodies against the nucleocapsid protein [4-7]. Furthermore, the viral nucleocapsid proteins, together with the viral glycoproteins G1 and G2, are promising candidates for the development of new vaccination strategies.

Recent studies have shown that proteins expressed in plants are suitable tools for the production of antigens. Bacterial toxins and various viral proteins have been successfully expressed in plants and found to be immunogenic [8-14].

These proteins were able to elicit specific humoral and mucosal immune responses when administered intraperitoneally or orally to animals and to protect the animals against the corresponding viral or bacterial infections. The expression of viral proteins in plants has the following advantages compared to other expression systems: firstly, there is no risk of contamination with mammalian viruses or other pathogens, and secondly, the production of antigens based on expression of the proteins is cheap and therefore of economic interest.

\section{Materials and Methods}

\section{Transgenic Tobacco Plants}

The transgenic tobacco plants were generated by transformation of Nicotiana tabacum cv. SR1 plants as described previously [14]. Briefly, leaves of the plant were immersed in MS liquid medium containing bacterial cells which harbored the recombinant binary plasmid pBinAR-PUU-S encoding the Puumala nucleocapsid $(\mathrm{N})$ protein sequences. After $48 \mathrm{~h}$, the leaves were washed with media containing cefotaxime and plated on selective agar media which contained kanamycin $(100 \mu \mathrm{g} / \mathrm{ml})$, cefotaxime $(500 \mu \mathrm{g} / \mathrm{ml})$, benzaladenine $2 \mu \mathrm{g} / \mathrm{ml}$ and naphthalene acetic acid $0.1 \mu \mathrm{g} / \mathrm{ml}$. Putative transformed shoots were further grown on kanamycin and analyzed for the expression of Puumala N protein.

Expression of Puumala Virus Nucleocapsid

Protein in Plants

\section{Transgenic Potato Plants}

The transgenic potato plants were generated by transformation of Solanum tuberosum cultivar Desiree tubers as described previously [14]. Briefly, microtubers cut into 1- to 2-mm discs were inoculated with bacterial cells which harbored the recombinant binary plasmid pBinAR-PUU-S encoding the Puumala N protein sequences for 2-3 days. After cocultivation, the discs were washed with medium containing cefotaxime $(500 \mu \mathrm{g} / \mathrm{ml})$. The discs were transferred onto MS medium containing kanamycin $(50 \mu \mathrm{g} / \mathrm{ml})$, cefotaxime $(300 \mu \mathrm{g} / \mathrm{ml})$, $\mathrm{GA}_{3} 0.02 \mu \mathrm{g} / \mathrm{ml}$ and zeatin $2 \mu \mathrm{g} / \mathrm{ml}$. Putative transformed shoots were further grown on kanamycin and analyzed for the expression of Puumala N protein [14].

\section{Sera and Antibodies}

Antiserum against recombinant $\mathrm{N}$ proteins of Puumala virus strain CG-1820 was induced in New Zealand white rabbits. Recombinant $\mathrm{N}$ proteins were generated as described elsewhere $[15,16]$. The rabbit antiserum against Puumala virus $\mathrm{N}$ protein was able to detect $0.125 \mathrm{ng}$ of recombinant viral $\mathrm{N}$ protein.

\section{Immunoblot Analysis}

Plant tissues, including leaves and roots, were harvested and dried for $72 \mathrm{~h}$ at $50^{\circ}$. Samples of leaf tissue powder $(200 \mu \mathrm{g})$ were dissolved in lysis buffer $[600 \mu \mathrm{l}$ with $0.001 \mathrm{M}$ Tris- $\mathrm{HCl}, 10 \%$ glycerol, $2 \%$ SDS, $5 \% \beta$-mercaptoethanol, $0.1 \%(\mathrm{w} / \mathrm{v})$ bromophenol blue, $\mathrm{pH}$ 8 ] and heated for $5 \mathrm{~min}$ at $95^{\circ}$. The insoluble fraction was removed by centrifugation at $17,000 \mathrm{~g}$ for $5 \mathrm{~min}$. Proteins were separated by SDS-PAGE and electroblotted on nitrocellulose filters. Transfer efficiency was monitored by ponceau staining (Sigma, Munich, Germany). Filters were blocked for $1 \mathrm{~h}$ and incubated with a $1 / 1,000$ dilution of rabbit antiserum. Peroxidase-conjugated antibodies were used to detect interaction of the rabbit antiserum with hantaviral proteins.

\section{Results}

\section{Phenotypic Characterization of Transgenic Tobacco}

\section{Plants Expressing Puumala N Protein}

Transgenic tobacco plants were grown in commercial garden mould at room temperature. Under these conditions, the growth rate of transgenic plants was comparable to that of normal tobacco plants. They developed 2-4 leaves per week and grew to a final height of $1.2 \mathrm{~m}$ (fig. 1). The growth rate did not differ from that of normal tobac$\mathrm{co}$, but the final height of the normal plants was slightly greater $(1.5 \mathrm{~m})$.

The leaves of transgenic tobacco plants were more slender but just as long as normal tobacco leaves. No other differences could be detected.

\section{Phenotypic Characterization of Transgenic Potato}

Plants Expressing Puumala N Protein

Transgenic potato plants were grown in commercial garden mould at room temperature. Under these condi- 

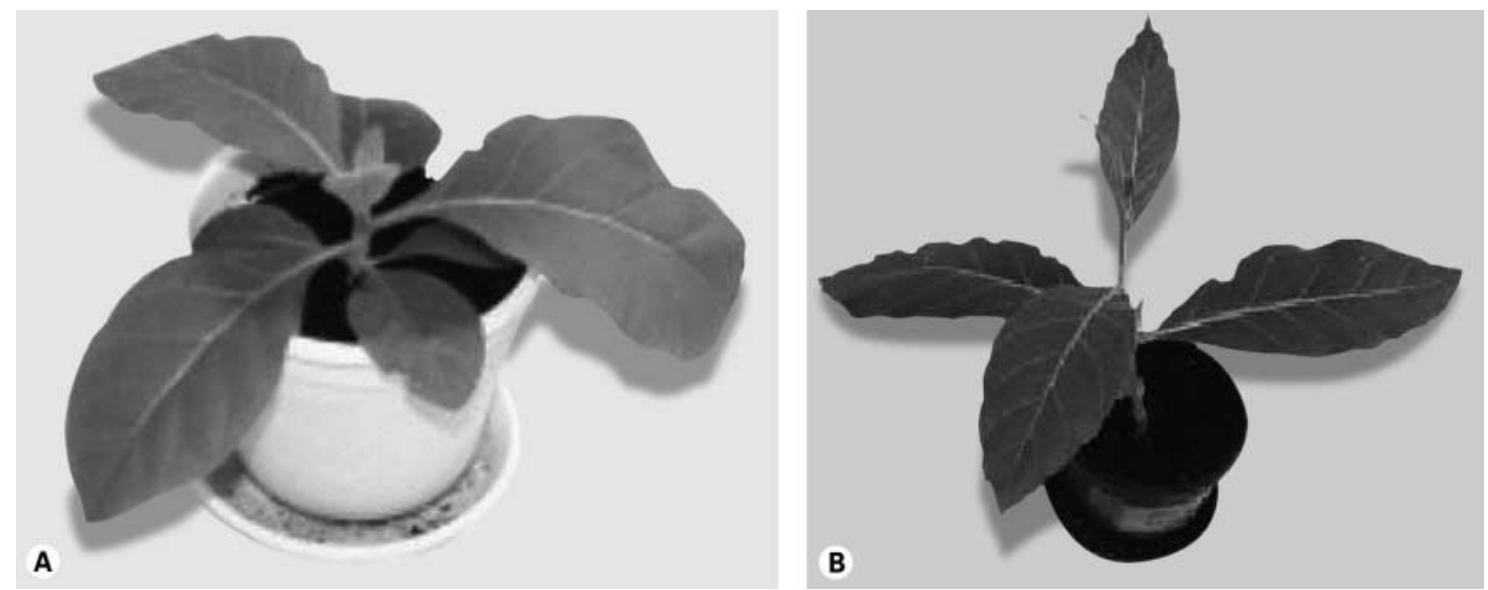

Fig. 1. Transgenic tobacco plant expressing the $\mathrm{N}$ protein of Puumala virus CG-1820 (B) in comparison to a normal tobacco plant $(\mathbf{A})$. Both plants were cultured for 10 weeks under identical conditions. The photographs of both plants were taken at the same scale.

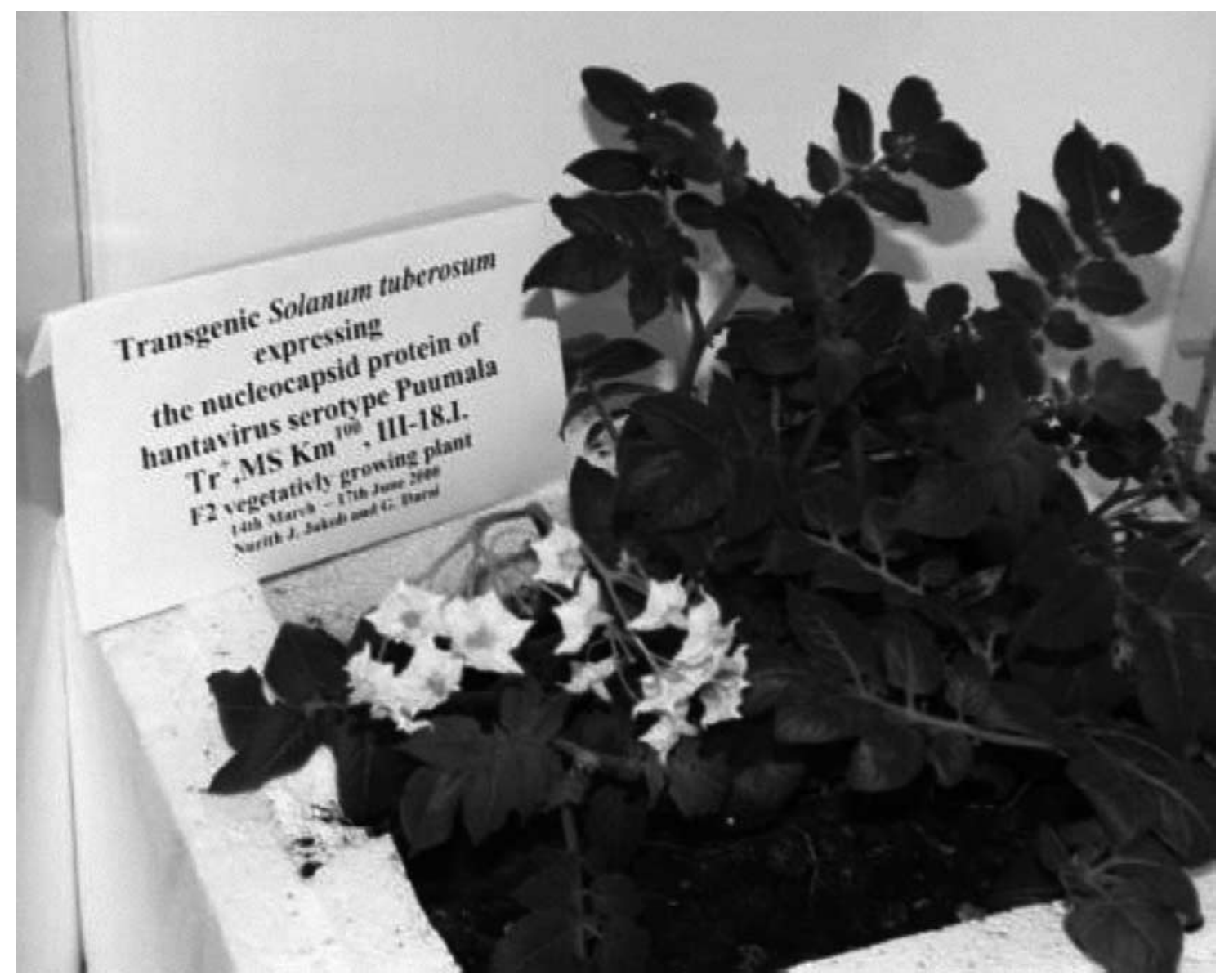

Fig. 2. Transgenic potato plant expressing the $\mathrm{N}$ protein of Puumala virus CG-1820 after 3 months of cultivation. 
Fig. 3. Western blot analyses of proteins of transgenic plants using rabbit antibodies generated against recombinant Puumala virus $\mathrm{N}$ protein. A Distribution of the expression of Puumala $\mathrm{N}$ protein in the leaves of transgenic tobacco (lanes 3-9) and transgenic potato plants (lanes 10-15). Lane 1: molecular weight marker; lane 2: recombinant $\mathrm{N}$ protein of Puumala virus $(5 \mathrm{ng})$. The arrow indicates the position of the Puumala virus $\mathrm{N}$ protein. B Distribution of the expression of Puumala $\mathrm{N}$ protein in the leaves and roots of two transgenic tobacco plants. Lanes 1 and 2: protein extracts of the roots (lane 1) and leaves (lane 2) of a transgenic tobacco plant (NT-PUU-F4-1); lanes 3 and 4: protein extracts of the leaves (lane 3 ) and roots (lane 4) of a second transgenic tobacco plant (NT-PUU-F4-2); lane 5: recombinant $\mathrm{N}$ protein of Puumala virus $(5 \mathrm{ng})$; lane 6: molecular weight marker. The arrow indicates the position of the Puumala virus $\mathrm{N}$ protein.

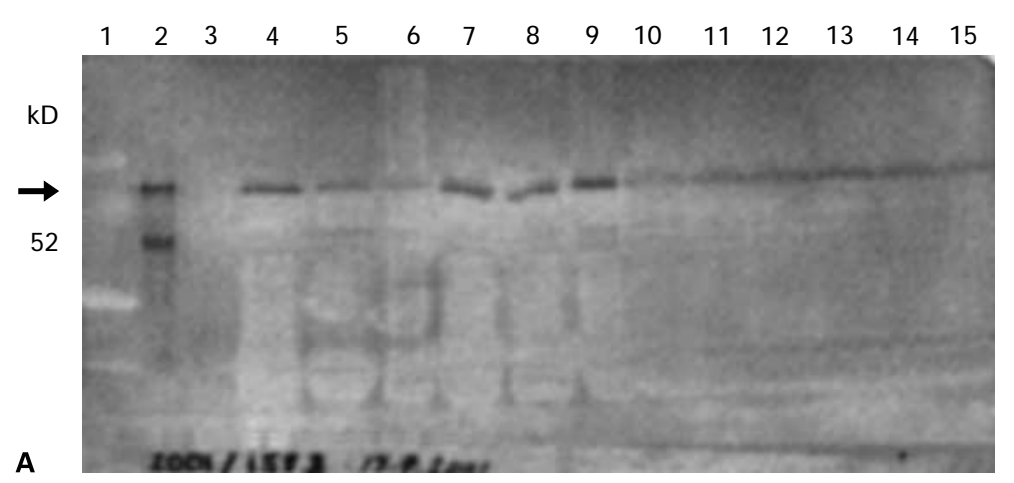

$\begin{array}{llllll}1 & 2 & 3 & 4 & 5 & 6\end{array}$

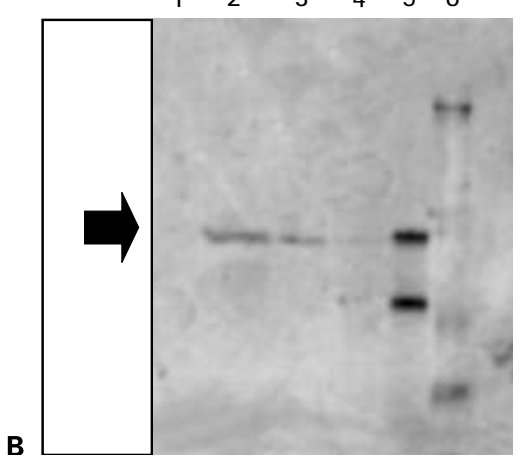

tions, the growth rate of transgenic plants was comparable to that of normal potato plants (fig. 2). They developed 4-6 leaves per week and grew to a final height of $0.8 \mathrm{~m}$ (fig. 1). The growth rate did not differ from that of normal potato plants, but the tubers were smaller (average weight of transgenic tubers $=19.8 \mathrm{~g}$, average weight of normal tubers $=30.7 \mathrm{~g}$ ) and the average number of tubers generated by each transgenic plant was smaller (average number of tubers per transgenic plant $=4.3$, average number of tubers per normal plant $=8.0$ ). No other differences could be detected.

\section{Distribution of Expression of Puumala N Protein in Transgenic Tobacco and Potato Plants}

In order to investigate the distribution of the expression of Puumala $\mathrm{N}$ protein in two transgenic tobacco plants, $200 \mu \mathrm{g}$ of powdered leaves and roots were analyzed by Western blots. The proteins were separated by SDS-PAGE and blotted onto nitrocellulose. As shown in figure 3, the expression of Puumala $\mathrm{N}$ protein differed between the two plants. In plant 1, expression could be detected in the leaves and roots. In contrast, expression of Puumala $\mathrm{N}$ protein in plant 2 could only be detected in the leaves.

Similar experiments were performed using leaves and tubers of transgenic potato plants. In all transgenic plants which were examined $(n=6)$, expression of Puumala $N$ protein could be detected in the leaves and tubers. The amount of expression of the protein was similar, i.e. no major differences could be detected between the transgenic potato plants (data not shown).

\section{Stability of Expression of Puumala N Protein in}

Different Generations of Transgenic Tobacco Plants

In order to investigate if the expression of Puumala $\mathrm{N}$ protein is stable in different generations of transgenic tobacco plants, the leaves of five generations (P, F1, F2, F3 and F4) of plants were analyzed. As shown in figure 4, no differences could be detected. The amount of Puumala $\mathrm{N}$ protein expressed in the leaves of these plants was 


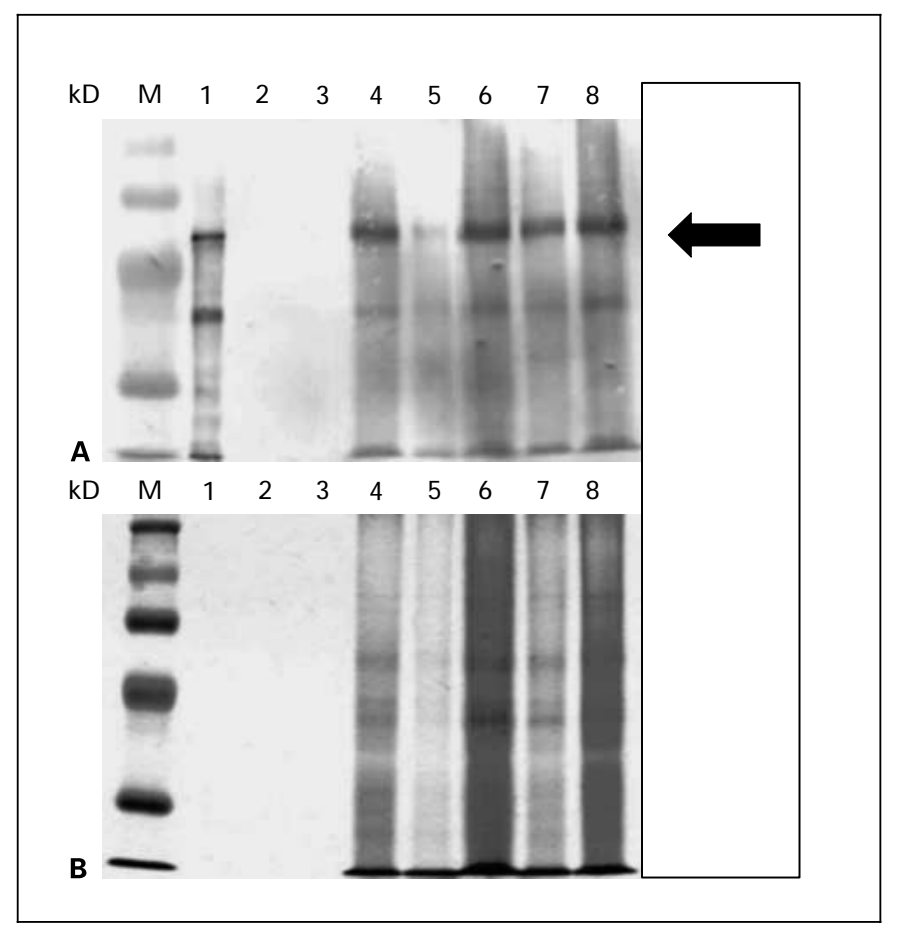

Fig. 4. Stability of expression of Puumala N protein in different generations of transgenic tobacco plants (P, F1, F2, F3 and F4). Lane 1: recombinant $\mathrm{N}$ protein of Puumala virus (5 ng); lanes 2 and 3: sample buffer serving as negative control; lanes 4-8: protein extracts of leaves of transgenic tobacco plants (lane 4: NT-PUU-P1; lane 5: NTPUU-F1-1; lane 6: NT-PUU-F2-1; lane 7: NT-PUU-F3-1; lane 8: NT-PUU-F4-1). $\mathrm{M}=$ Molecular weight marker. The arrow indicates the position of the Puumala virus N protein. A Western blot analyses of proteins of transgenic plants using rabbit antibodies generated against recombinant Puumala virus N protein. B Coomassie staining of the SDS-PAGE.

about the same in each generation. This indicates that integration of the foreign DNA is stable, without any selection pressure, and that the expression is not reduced by silencing mechanisms, at least under the conditions used here.

\section{Discussion}

Transgenic plants expressing foreign genes are a suitable system for the production of relevant immunogens in high amounts that can be used for development of a new generation of vaccines against a variety of infectious diseases. In the present study, the expression of the $\mathrm{N}$ protein of hantavirus serotype Puumala in tobacco and potato plants was investigated.
The hantaviral recombinant $\mathrm{N}$ proteins obtained from transgenic tobacco and potato plants have been shown to be able to elicit specific humoral and mucosal immune responses when administered intraperitoneally in rabbits and mice [14]. Oral immunization of mice is under investigation. Only recently, it was shown that oral immunization of mice with hepatitis B surface antigen expressed in transgenic plants was successful [17]. Hence, the expression of hantaviral antigens in transgenic plants is a suitable approach for the development of a vaccine against hantaviral infections. At present, there is no commercially available hantaviral vaccine. The limiting factor is that it is still not possible to express hantaviral glycoproteins with high manufacturing efficiency. A variety of new generations of hantaviral vaccines are still at an experimental stage [18-20].

The expression of viral proteins in plants has the following major advantages: firstly, there is no risk of contamination with mammalian viruses or other pathogens, and secondly, the production of high amounts of antigens is cheap and therefore of great economic interest. The possibility of antigen expression in high amounts facilitates the characterization of protein interactions in pharmacokinetic studies and in addition enables basic science on the further structural characterization of the viral antigens by crystallization.

Finally, transgenic plants expressing hantaviral antigens could be used for oral field immunizations of rodents which serve as vectors, thereby eradicating the main pathway of transmission of hantaviruses to humans.

\section{Acknowledgment}

This study was supported by the Sächsisches Landesamt für Umwelt und Geologie (AZ:13-8811.61/111). 


\section{References}

1 Schmaljohn CS, Dalrymple JM: Analysis of Hantaan virus RNA: Evidence for a new genus of bunyaviridae. Virology 1983;131:482-491.

2 Gött P, Stohwasser R, Darai G, Bautz EKF: RNA binding of recombinant nucleocapsid proteins of hantaviruses. Virology 1993;194: 332-337.

3 Gött P, Zöller L, Yang S, Darai G, Bautz EKF: A major antigenic domain of hantaviruses is located on the aminoproximal site of the viral nucleocapsid protein. Virus Genes 1997;14: 31-40.

4 Zöller L, Scholz J, Stohwasser R, Giebel LB, Sethi KK, Bautz EKF, Darai G: Immunoblot analysis of the serological response in Hantavirus infections. J Med Virol 1989;27:231-237.

5 Groen J, Dalrymple J, Fisher-Hoch S, Jordan JG, Clement JP, Osterhaus AD: Serum antibodies to structural proteins of Hantavirus arise at different times after infection. $\mathbf{J}$ Med Virol 1992;37:283-287.

6 Lundkvist A, Horling J, Athlin L, Rosen A, Niklasson BJ: Neutralizing human monoclonal antibodies against Puumala virus, causative agent of nephropathia epidemica: A novel method using antigen-coated magnetic beads for specific B cell isolation. J Gen Virol 1993; 74:1303-1310.

7 Elgh F, Wadell G, Juto P: Comparison of the kinetics of Puumala virus specific IgM and IgG antibody responses in nephropathia epidemica as measured by a recombinant antigen-based enzyme-linked immunosorbent assay and an immunofluorescence test. J Med Virol 1995; 45:146-150.
8 Haq TA, Mason HS, Clements JD, Arntzen CJ: Oral immunization with a recombinant bacterial antigen produced in transgenic plants. Science 1995;268:714-716.

9 Mason HS, Ball JM, Shi JJ, Jiang X, Estes MK, Arntzen CJ: Expression of Norwalk virus capsid protein in transgenic tobacco and potato and its oral immunogenicity in mice. Proc Natl Acad Sci USA 1996;28:5335-5340.

10 Yusibov V, Modelska A, Steplewski K, Agadjanyan M, Weiner D, Hooper DC, Koprowski H: Antigens produced in plants by infection with chimeric plant viruses immunize against rabies virus and HIV-1. Proc Natl Acad Sci USA 1997;94:5784-5798.

11 Modelska A, Dietzschold B, Sleysh N, Fu ZF, Steplewski K, Hooper DC, Koprowski H, Yusobov V: Immunization against rabies with plant-derived antigen. Proc Natl Acad Sci USA 1998;95:2481-2485.

12 Carrillo C, Wigdorovitz A, Oliveros JC, Zamorano PI, Sadir AM, Gomez N, Salinas J, Escribano JM, Borca MV: Protective immune response to foot-and-mouth disease virus with VP1 expressed in transgenic plants. J Virol 1998;72:1688-1690.

13 Castanon S, Marin MS, Martin-Alonso JM, Boga JA, Casais R, Humara JM, Ordas RJ, Parra F: Immunization with potato plants expressing VP60 protein protects against rabbit hemorrhagic disease virus. J Virol 1999;73: 4452-4455.

14 Kehm R, Jakob NJ, Welzel TM, Tobiasch E, Viczian O, Jock S, Geider K, Süle S, Darai G: Expression of immunogenic Puumala virus nucleocapsid protein in transgenic tobacco and potato plants. Virus Genes 2001;22:73-83.
15 Gött P, Zöller L, Yang S, Stohwasser R, Bautz EKF, Darai G: Antigenicity of hantavirus nucleocapsid proteins expressed in E. coli. Virus Res 1991;19:11-16.

16 Zöller L, Yang S, Bautz EKF, Darai G: Use of recombinant proteins of the Hantaan and nephropathia epidemica serotypes of Hantaviruses as immunodiagnostic antigens. J Med Virol 1993;39:200-207.

17 Kong Q, Richter L, Yang YF, Arntzen CJ, Mason HS, Thanavala Y: Oral immunization with hepatitis B surface antigen expressed in transgenic plants. Proc Natl Acad Sci USA 2001;98:11539-11544.

18 Hooper JW, Custer DM, Thompson E, Schmaljohn CS: DNA vaccination with the Hantaan virus $M$ gene protects hamsters against three of four HFRS hantaviruses and elicits a high-titer neutralizing antibody response in rhesus monkeys. J Virol 2001;75: 8469-8477.

19 Bucht G, Sjolander KB; Eriksson S, Lindgren L, Lundkvist A, Elgh F: Modifying the cellular transport of DNA-based vaccines alters the immune response to hantavirus nucleocapsid protein. Vaccine 2001;19:3820-3829.

20 Koletzki D, Schirmbeck R, Lundkvist A, Meisel H, Kruger DH, Ulrich R: DNA vaccination of mice with a plasmid encoding Puumala hantavirus nucleocapsid protein mimics the B-cell response induced by virus infection. $\mathrm{J}$ Biotechnol 2001;17:73-78. 